Texas A\&M University-San Antonio

Digital Commons @ Texas A\&M University-San Antonio

Criminology and Criminal Justice Faculty

Publications

College of Arts and Sciences

$10-2019$

Construing the Legality of Solitary Confinement: Analysis of

United States Federal Court Jurisprudence

Claire Nolasco

Michael S. Vaughn

Follow this and additional works at: https://digitalcommons.tamusa.edu/crim_faculty

Part of the Criminology and Criminal Justice Commons 


\section{CONSTRUING THE LEGALITY OF SOLITARY CONFINEMENT: ANALYSIS OF UNITED STATES FEDERAL COURT JURISPRUDENCE INTRODUCTION}

Testifying before Congress, United States (“U.S.”) Supreme Court Justice Anthony Kennedy warned of the ills of solitary confinement and criticized the use of "isolation cells" (U.S. House of Representatives, 2015). Justice Kennedy also noted in a concurring opinion (Davis v. Ayala, 2015, p. 2209) that some inmates spend decades in solitary confinement in a "windowless cell no larger than a typical parking spot for 23 hours a day...and... when...[let out they are]...allowed little or no opportunity for conversation or interaction with anyone.” In fact, since 1890, the Supreme Court has known of "the human toll wrought by extended terms of isolation.” The Court warned that isolation cells cause "a further terror and a peculiar mark of infamy” (Davis v. Ayala, 2015, p. 2210, quoting In re Medley, 1890, p. 168), elaborating that a “considerable number of...prisoners fell, after even a short [solitary] confinement, into a semifatuous condition... and others [become] violently insane; others, still, commit[ ] suicide" (Davis v. Ayala, 2015, p. 2210, quoting In re Medley, 1890, p. 170; Freckelton, 2011; Rivlin, et al., 2013).

Solitary confinement refers to the practice of correctional administrators of placing an inmate in restricted housing or in a long-term supermax security housing (McGinnis et al., 2014, 2008b; Shames et al., 2015). Solitary confinement includes isolation through disciplinary or punitive segregation, administrative segregation, and protective custody (Frost \& Monteiro, 2016; Shames et al., 2015). Disciplinary or punitive segregation involves short term confinement in a restrictive housing unit to sanction inmates for specific infractions. It is imposed after a disciplinary hearing and requires due process safeguards (O'Keefe, 2008). Administrative 
segregation is used to separate inmates deemed a significant threat to institutional security. It refers to long-term classification to the supermax unit or facility within a correctional system (Frost \& Monteiro, 2016). Protective custody refers to the practice of segregating inmates for their own protection because they are at high risk of victimization. Inmates placed in solitary confinement experience psychological trauma (Haney, 2003; Johnson, 2016; Shoats v. Horn, 2000; Williams v. Secretary Pennsylvania Department of Corrections, 2017), stupor, difficulties with thinking and concentration, obsessional thinking, agitation, irritability, and difficulty tolerating external stimuli (Grassian, 2006, p. 331), anxiety and panic (Haney \& Lynch, 1997, p. 500), depression, post-traumatic stress disorder, psychosis, hallucinations, paranoia, claustrophobia, and suicidal ideation (Freckelton, 2011; Haney \& Lynch, 1997; Kupers, 2017), physical harm, such as high rates of suicide (Hayes, 2017; Rivlin, et al., 2013) and selfmutilation (Grassian, 1983), weight loss, hypertension, heart abnormalities, and aggravation of pre-existing medical problems (Korn, 1988; Reiter, 2016). Despite the well-researched trauma wrought by even short periods of segregation (Haney, 2018; Smith, 2006), the U.S. correctional system implements this practice as a primary means of disciplining inmates or maintaining institutional peace and order (Lee \& Prabhu, 2015; Obama, 2016; U.S. Department of Justice, 2016), which runs contrary to the position taken by the National Commission on Correctional Health Care (2016).

The Bureau of Justice Statistics, for instance, reports that among a sample of 91,177 adult inmates in 233 state and federal prisons and 357 local jails in 2011-2012, 4.4\% of state and federal inmates and $2.7 \%$ of jail inmates were confined in administrative segregation (Beck, 2015). Almost $20 \%$ of prison inmates and $18 \%$ of jail inmates were placed in restrictive housing 
CONSTRUING THE LEGALITY OF SOLITARY CONFINEMENT

(e.g., disciplinary or administrative segregation or solitary confinement) in the prior 12 months or since coming to their current facility, while $29 \%$ of prison inmates and $22 \%$ of jail inmates with symptoms of serious psychological distress were placed in restrictive housing in the prior 12 months (Beck, 2015). The substantial portion of inmates placed in segregation increased inmate litigation questioning its legality under the Fifth, Eighth, and Fourteenth Amendments of the U.S. Constitution (Allen-Bell, 2012; Henderson, 2015).

The evolution of Supreme Court jurisprudence on legal standards affecting an inmate's liberty interest to be free from segregation can be traced back to Hewitt v. Helms (1983). Prior to Sandin v. Conner (1995), the analysis focused on whether prison regulations contained “mandatory” language protecting a liberty interest instead of the confinement conditions experienced by the inmate (Beverati v. Smith, 1997, p. 503; Marcus, 2015, p. 1169). After Sandin, the analysis revolved around whether the segregation conditions imposed "atypical and significant hardship” on the inmate beyond the routine prison experience (Benjamin v. Fraser, 2001; Marcus, 2015). In Sandin (1995, pp. 485-487), the Court held that an inmate’s 30-days disciplinary segregation did not implicate a liberty interest because it did not “drastically deviate” from the basic conditions of his sentence, involve a "major disruption” of his environment,” or “inevitably affect the duration of his sentence.” Plaintiff's 30-day disciplinary segregation was not excessive compared to "similar, but totally discretionary, confinement in either duration or degree of restriction” (Sandin v. Conner, 1995, pp. 486-487).

Similar to Sandin, the Court in Wilkinson v. Austin (2005) considered the nature of the more-restrictive confinement and its duration. In Wilkinson (2005, p. 213), however, the Court explained that an inmate's assignment to a maximum-security prison with "highly restrictive 
conditions" imposed "atypical and significant hardship" because of "significant differences" between conditions at the maximum-security prison and "most solitary confinement facilities." The Court noted that the inmate's placement in the maximum security prison was indefinite and, after an initial 30-day review, was only reviewed annually. In addition, placement in the maximum security prison disqualified the inmate from parole consideration (Wilkinson v. Austin, 2005).

Despite these pronouncements by the Supreme Court, lower courts have vacillated in construing what constitutes atypical and significant hardship (Johnson, 2016; Marcus, 2015). The Court did not define any baseline in Wilkinson v. Austin (2005) from which to compare whether the questioned segregation imposes atypical and significant hardship on the inmate. Federal courts have consequently developed varying interpretations and outcomes when faced with inmate litigation challenging conditions of their segregation.

\section{Objectives}

This article examines precedent in the various 12 U.S. Courts of Appeals (the 11 numbered circuits and the D.C. Circuit) to determine differences and similarities among federal circuit case law when interpreting various aspects of inmate segregation, namely: liberty interests, atypical and significant hardships, and baselines of comparison. The article concludes that despite the voluminous research pointing out the deleterious effects of solitary confinement on inmates' mental and physical health, these effects play a relatively minor role in the judicial assessment of the constitutionality of administrative segregation and punitive isolation. 
CONSTRUING THE LEGALITY OF SOLITARY CONFINEMENT

\section{METHOD}

The WESTLAW database contains electronic copies of all published and unpublished court decisions. A keyword search was used to gather cases on inmate segregation decided by all 12 U.S. Circuit Courts of Appeals. The advanced search parameters required that the terms "Wilkinson v. Austin” AND “atypical and significant hardship” appeared in the "main body” of the case and that both reported and unreported cases filed and decided after January 1, 2005 be searched for relevant cases $(N=110)$. The authors focused on cases citing Wilkinson v. Austin (2005) which involved extreme conditions of administrative segregation in a supermax facility in contrast to the more routine conditions of disciplinary segregation in Sandin v. Conner (1995). The intent was to examine inmate litigation alleging that their conditions were sufficiently extreme so as to trigger the standard of atypical and significant hardship. The analysis did not include solitary confinement cases where inmates did not challenge the legality of their confinement, such as death row inmates alleging the unconstitutionality of the death penalty or segregated inmates alleging excessive use of force. Since the analysis specifically focused on inmate litigation attacking the legality of their solitary confinement conditions, the search terms were limited to the Supreme Court's legal standard of atypical and significant hardship.

The article analyzes a population of cases and not a sample. The authors then read each case individually and determined that not all cases were relevant to the article, either because the case did not involve inmate segregation, only discussed atypical and significant hardship briefly, made reference to Wilkinson v. Austin (2005) in passing, did not contain sufficient facts to enable full analysis, or contained a decision that either affirmed or repealed a lower court's decision, without discussing the facts. Also, some of the cases were repeated because of the appeal 
process through the federal courts. The deletion process also excluded all criminal cases, yielding a total of 68 circuit court cases. The authors conducted an inductive doctrinal analysis (Nolasco, Vaughn, \& del Carmen, 2010) to synthesize circuit court decisions on legal concepts surrounding inmate segregation, creating a framework from which to present the analysis (Nolasco, et al., 2015).

\section{ANALYSIS OF CIRCUIT COURT PRECEDENT}

\section{Identification of Liberty Interests within Segregation}

A long line of precedent emphasize that incarcerated persons retain only a "narrow range of protected liberty interests” due to the "necessary withdrawal or limitation of many privileges and rights” (Abbott v. McCotter, 1994, p. 1442; Hewitt v. Helms, 1983, p. 467; In re Long Term Admin. Segregation, 1999, p. 468; Price v. Johnston, 1948, p. 285; Rezaq v. Nalley, 2012, p. 1011). To prevail on a 42 U.S.C. $§ 1983$ claim, an inmate must demonstrate that: (1) he or she was deprived of a right guaranteed by the Constitution or federal laws; and, (2) the deprivation occurred "under color of state law" (Bingham v. Thomas, 2011, p. 1175). A §1983 action based on the Fourteenth Amendment's Due Process Clause must allege a deprivation of a protected liberty interest (Bass v. Perrin, 1999; Smith v. Deemer, 2016). Liberty interests are violated, for instance, when state action alters the term of an inmate's imprisonment (e.g., revocation of good time credit) or imposes an atypical and significant hardship beyond the ordinary conditions of prison life (Burnette v. Fahey, 2012; Greenholtz v. Inmates, 1979; Hewitt v. Helms, 1983; Lovelace v. Lee, 2006; Sandin v. Conner, 1995; Smith v. Deemer, 2016; Vitek v. Jones, 1980; Wilkerson v. Goodwin, 2014; Wilkinson v. Austin, 2005; Wolff v. McDonnell, 1974). The requirement of procedural due process must be based on the express provisions of a state statute, 
CONSTRUING THE LEGALITY OF SOLITARY CONFINEMENT

regulation, or policy granting the inmate a protected liberty interest (Meachum v. Fano, 1976;

Prieto v. Clarke, 2015).

Appendix 1 describes how the different U.S. Circuit Courts of Appeals after Wilkinson v. Austin (2005) interpret three issues surrounding inmate segregation, focusing on the identification of liberty interests, atypical and significant hardships, and baselines of comparison. An inmate does not have any liberty interest in avoiding: (1) change in status or classification “because he is not entitled to a particular degree of liberty in prison” (Keck v. Zenon, 2007, p. 818; Meachum v. Fano, 1976, p. 225; Templeman v. Gunter, 1994, p. 369); (2) disciplinary segregation imposed as a sanction after a due process hearing (Hallman v. Cate, 2012; Keck v. Zenon, 2007; Rodriguez v. Pearson, 2012) or pending investigation for another inmate’s death (Skinner v. Cunningham, 2005), unless it “inevitably” lengthens a prisoner's sentence (Carson v. Johnson, 1997, p. 821); and, (3) administrative segregation based on a legitimate penological interest (McKeithan v. Beard, 2009; Orellana v. Kyle, 1995).

The First Circuit considered the duration and exigency of the punitive segregation when it upheld the 40-day segregation of an inmate without a hearing "for his own sake and for the protection of others-while investigating the circumstances” (Skinner v. Cunningham, 2005, p. 486; Cf. Reardon v. United States, 1991, p. 1522). The Second Circuit considers both the duration and conditions of an inmate's segregation (Palmer v. Richards, 2004; Tellier v. Fields, 2000). The Second Circuit found that an inmate had a liberty interest in avoiding administrative segregations lasting 180 (Kalwasinski v. Morse, 1999) and 305 days (Colon v. Howard, 2000). Confinements “of an intermediate duration—between 101 and 305 days” require detailed scrutiny of whether the inmate experienced atypical and significant hardship, but segregations 
CONSTRUING THE LEGALITY OF SOLITARY CONFINEMENT

longer than 305 days definitely trigger a liberty interest, which require due process protections (Colon v. Howard, 2000, p. 232).

The Third Circuit also considers both the length of segregation and conditions of confinement to determine whether the inmate was deprived of his liberty interests (Burns v. Pa. Dep't. of Corr., 2001). In Diaz v. Canino (2012), inmate Diaz was placed in disciplinary segregation because prison officials received information that he was planning to escape. After a misconduct hearing, he was found guilty and sentenced to 360-days in disciplinary confinement. While in disciplinary confinement, Diaz was subjected to “continuous searches,” "regular relocation of his cell,” and “was unable to sleep” because his cell lights “remained turned on” (p. 216). The Third Circuit held that: (1) the conditions and the length of Diaz's segregation did not impose atypical and significant hardship; and, (2) Diaz did not provide any baseline of comparison since he did not specify the conditions experienced by other inmates who were not in disciplinary segregation.

Fourth Circuit precedent hold that a death row inmate does not have any protected liberty interest in avoiding isolation on death row (Prieto v. Clarke, 2015). Prieto involved an inmate who was confined to death row pursuant to Virginia state policy. Under the policy, death row inmates cannot be placed in any alternative confinement, live in isolated cells, and have more onerous and restrictive visitation and recreation privileges compared to general population inmates.

The Fifth Circuit denied the existence of a protected liberty interest in the following cases: (1) 14-days of disciplinary segregation of a federal inmate, resulting in a three-month loss of commissary, visitation, and telephone privileges (Watkins v. Lnu, 2013); (2) administrative 
segregation without “extraordinary circumstances” (Cruz v. Forrest, 2009, p. 901; Hernandez v. Velasquez, 2008, pp. 562-564; Huff v. Thaler, 2013, p. 311; Jimenez v. McQueen, 2012; Luken v. Scott, 1995, p. 193; Pichardo v. Kinker, 1996, pp. 612-613; Wilkerson v. Goodwin, 2014, p. 853); and, (3) an inmate's custodial classification (Hernandez v. Velasquez, 2008; Moody v. Baker, 1988; Rollins v. Cain, 2011), unless the inmate experienced atypical and significant hardship (Bailey v. Fisher, 2016). The Fifth Circuit cautioned that prison officials should be granted “the widest possible deference” in classifying prisoners' custodial status when necessary “to maintain security and preserve internal order” (Hernandez v. Velasquez, 2008, p. 562; McCord v. Maggio, 1991; Pichardo v. Kinker, 1996, pp. 612-613). Thus, inmates have few liberty interests when balanced against the prison officials’ custodial and security interests.

In Hernandez v. Velasquez (2008), an inmate serving a life sentence for capital murder was placed on lockdown status after he was suspected of being a gang member and was planning a riot with a rival prison gang. While on lockdown for approximately one year, he was confined to a two-person cell measuring five-feet by nine-feet and was allowed to leave his cell only for showers, medical appointments, and family visits. The Fifth Circuit held that an inmate maintains a due process challenge to his custodial classification only when he or she “demonstrates extraordinary circumstances” (p. 562). The lockdown conditions in Hernandez, however, did not impose an atypical or significant hardship because they were "comparable to, if not less severe than, those found unactionable in other cases” (p. 563). Temporary lockdown to prevent gang violence was a normal condition of confinement that an inmate could expect while in prison (Hernandez v. Velasquez, 2008; Wagner v. Hanks, 1997).

According to the Sixth Circuit, an inmate does not possess any liberty interest in avoiding 
61-days of administrative segregation (Jones v. Baker, 1998; Joseph v. Curtin, 2010; RimmerBey v. Brown, 1995), transfer to a higher security level facility (Joseph v. Curtin, 2010), or transfer from one state correctional institution to another that is not a supermax facility (Bell $v$. Wilkinson, 2005) unless the conditions imposed atypical and significant hardship. An initial placement in administrative segregation or an increase in security classification does not constitute an atypical and significant hardship because a prisoner "has no constitutional right to remain incarcerated in a particular prison or to be held in a specific security classification” (Harbin-Bey v. Rutter, 2005, p. 577; Harden-Bey v. Rutter, 2008, pp. 794-795).

Under Seventh Circuit precedent, substantial lengths or unusually harsh conditions in segregation may trigger a liberty interest (Marion v. Columbia Corr. Inst., 2009; Means v. Larson, 2014; Townsend v. Cooper, 2014). Short periods of segregation for 10-days (Smith v. Birkey, 2011), one-month (Means v. Larson, 2014), or 78-days (Obriecht v. Raemisch, 2014), transfers to discretionary nonpunitive administrative segregation pending investigation (Townsend v. Fuchs, 2008), or transfers to less restrictive segregation (Furrow v. Marberry, 2011; Lagerstrom v. Kingston, 2006) do not implicate a liberty interest (Toston v. Thurmer, 2012; Earl v. Racine Cnty. Jail, 2013; Lekas v. Briley, 2005; Orr v. Larkins, 2010; Richardson v. Runnels, 2010).

According to the Eighth Circuit, an inmate does not enjoy any "constitutional right to remain in a particular institution” (Goff v. Burton, 1993, p. 737; Murphy v. Mo. Dep't of Corr., 2004, p. 503). Prison administrators may transfer a prisoner "for whatever reason or for no reason at all” (Olim v. Wakinekona, 1983, p. 250). In Saylor v. Nebraska (2016), for example, an inmate who was sexually assaulted by other inmates was transferred to protective custody status 
at another correctional facility that could provide him proper medical treatment and counseling. The Eighth Circuit held that the Fourteenth Amendment Due Process Clause does not protect an inmate against transfer from one institution to a "comparable prison" for the "sole purpose” of “continuing his psychiatric care” (Saylor v. Nebraska, 2016, p. 647).

In Estate of DiMarco v. Wyoming Department of Corrections (2007), the Tenth Circuit held that the plaintiff did not have a liberty interest in avoiding protective custody. Here, a routine physical examination of an inmate transferred to the women's state prison revealed that she was anatomically male. Although prison officials determined that she was a low security risk during initial placement, they recommended segregation for safety reasons, her “physical condition” as a hermaphrodite, and the “need to tailor programs” for her (p. 1337). After initial placement, her status was reviewed every 90-days and she was furnished written copies of the decision after each periodic review. While in protective confinement, the plaintiff had access to almost all amenities provided to general population inmates, such as psychiatric and counseling sessions, adequate clothing, the same food as general population inmates, access to prison staff and medical care, regular reading materials, and various other personal hygiene items. The Tenth Circuit explained that plaintiff was placed in segregation for safety reasons because other inmates in general population who were sexual assault victims may be fearful of her or may threaten her for other reasons. Conditions of her confinement were not extreme and, although “Spartan,” were not atypical of protective custody (p. 1343). The court concluded that administrative segregation did not extend the duration of her sentence- - she was released after serving 14 months. 
CONSTRUING THE LEGALITY OF SOLITARY CONFINEMENT

\section{Determining “Atypical and Significant Hardship”}

Since courts consider the severity and duration of the restrictive conditions to determine atypical and significant hardship (Hardaway v. Meyerhoff, 2013; Harden-Bey v. Rutter, 2008; Palmer v. Richards, 2004; Serrano v. Francis, 2003; Shoats v. Horn, 2000; Wilkerson v. Goodwin, 2014), inmates successfully claim a protected liberty interest if they present evidence on the confinement conditions in administrative segregation (Bailey v. Fisher, 2016; Evans v. Vinson, 2011). Some circuit courts aggregate the time spent at different facilities to determine whether its duration imposed atypical and significant hardship. In Giano v. Selsky (2001, p. 226), the Second Circuit aggregated the inmate's administrative segregation at two different facilities because "the two periods of confinement were based on the same administrative rationale" and conditions of confinement were "identical at both facilities.” The Third Circuit aggregated the plaintiff's cumulative eight-year period of administrative custody in multiple state and federal institutions (Shoats v. Horn, 2000), while the Fifth Circuit aggregated time spent in different facilities under the same prison system to determine the total duration of segregation (Wilkerson v. Goodwin, 2014). The Fifth Circuit suggested that "two-and-a-half years" (30 months) of administrative segregation is a "threshold of sorts for atypicality," so that "18-19 months of segregation under even the most isolated of conditions” may not implicate a liberty interest while a 40-year lockdown of inmate is unconstitutional (Bailey v. Fisher, 2016, p. 476; Wilkerson v. Goodwin, 2014, p. 855). The Sixth Circuit held that the duration of administrative segregation imposed atypical and significant hardship on the inmate in the following cases: (1) 8-years of administrative segregation (Harris v. Caruso, 2012); (2) indefinite placement in administrative segregation (Harden-Bey v. Rutter, 2008; Hatch v. District of Columbia, 1999; Iqbal v. Hasty, 
2007; Perkins v. Kansas Dep't. of Corr., 1999; Serrano v. Francis, 2003; Shoats v. Horn, 2000;

Skinner v. Cunningham, 2005; Stephens v. Cottey, 2005); and (3) inmate’s segregation continued indefinitely and affected his eligibility for parole (Heard v. Caruso, 2009).

The Seventh Circuit examines the "combined import" of the duration and conditions of segregation (Hardaway v. Meyerhoff, 2013, p. 743; Marion v. Columbia Corr. Inst., 2009, p. 697). Relatively short periods of segregation such as 59-days (Townsend v. Fuchs, 2008) or sixmonths (Whitford v. Boglino, 1995) without "exceptionally harsh conditions” do not give rise to a liberty interest, unless segregation "significantly altered" the conditions of the inmate's sentence (Hardaway v. Meyerhoff, 2013, p. 744; Whitford v. Boglino, 1995, p. 533). Inmates, however, have a liberty interest in avoiding lengthy or extreme terms of segregation (Bryan v. Duckworth, 1996; Holly v. Woolfolk, 2005; Hoskins v. Lenear, 2005; Marion v. Columbia Corr. Inst., 2009; Townsend v. Fuchs, 2008; Whitford v. Boglino, 1995). If the conditions of segregation were "significantly harsher" than those in the normal prison environment, then longterm confinement, such as “a year of segregation” may implicate liberty interests, "where a few days or weeks might not” (Hardaway v. Meyerhoff, 2013, p. 743; Marion v. Columbia Corr. Inst., 2009, pp. 697-698). Under Seventh Circuit precedent, “even extremely harsh” prison conditions by themselves may "not be so atypical" as to create a protected liberty interest (Townsend v. Fuchs, 2008, p. 769). Discretionary segregation imposed for "administrative, protective, or investigative purposes" is an "ordinary incident of prison life" that inmates "should expect to experience” while incarcerated (Lekas v. Briley, 2005, p. 611; Meriwether v. Faulkner, 1987, p. 414; Wagner v. Hanks, 1997, pp. 1175-1176).

The Ninth Circuit adopts a context-dependent, "fact-by-fact consideration” (Ramirez v. 
Galaza, 2003, p. 861) that focuses on the conditions of confinement (Chappell v. Mandeville, 2013; Duffy v. Riveland, 1996; McQuillion v. Duncan, 2002; Mitchell v. Dupnik, 1996; Mujahid v. Meyer, 1995; Myron v. Terhune, 2007). The court considers three factors: (1) whether the conditions “mirrored” those in "analogous discretionary confinement settings” (e.g., administrative segregation and protective custody); (2) the "duration and intensity” of the conditions; and (3) whether the change in confinement would "inevitably affect” the duration of the inmate’s sentence (Chappell v. Mandeville, 2013, pp. 1064-1065; Ramirez v. Galaza, 2003, p. 861).

The Tenth Circuit examines “several nondispositive factors” to determine whether segregation imposes atypical and significant hardship on the routine aspects of prison life: (1) the segregation "relates to and furthers a legitimate penological interest;” (2) the confinement conditions are "extreme” (Fogle v. Pierson, 2006, p. 1265); (3) the segregation "increases the duration of confinement;" and (4) the segregation is "indeterminate” (Abbott v. McCotter, 1994, p. 1442; Deberry v. Davis, 2012, p. 801; Estate of DiMarco v. Wyoming Department of Corrections, 2007, p.1342; McAdams v. Wyoming Department of Corrections, 2014, p. 721; Rezaq v. Nalley, 2012, pp. 1011-1012; Stallings v. Werholtz, 2012, p. 844; Suarez v. Palomino, 2014, p. 735).

The Tenth Circuit upheld the constitutionality of administrative segregation in the following cases: (1) confinement of a former defense contractors under special administrative measures at the federal prison’s Administrative Maximum Facility (“ADX”) in Florence, Colorado after conviction for federal conspiracy to export classified defense information and divulging national security secrets (Gowadia v. Stearns, 2014); (2) long-term segregation for 
potentially violent inmates, including plaintiff's more than 400-days segregation in maximum security due to "verbal and written threats to kill prison employees who laid hands on him" (Marshall v. Ormand, 2014, pp. 661-662); (3) long-term administrative segregation of an inmate pending an assault investigation for safety reasons and because of prior disciplinary history of serious infractions, including gang membership and assault of other inmates (Jordan v. FBOP, 2006; McAdams v. Wyoming Department of Corrections, 2014); and, (4) transfer of inmates convicted of terrorism-related offenses to ADX in Florence, CO (Rezaq v. Nalley, 2012) due to national security concerns after the September 11, 2001 terrorist attacks (U.S. v. Rahman, 1999; U.S. v. Rezaq, 1998).

The Tenth Circuit observed that ADX conditions: (1) are not "extreme” although more restrictive than other segregation units —plaintiffs had "control over the lights in their cells," access to outdoor recreation, maintained contact and communication with staff and other inmates, and were allowed five "no contact social visits” and “two 15-minute phone calls per month” (Rezaq v. Nalley, 2012, p. 1014); (2) are “substantially similar to” conditions “routinely imposed” in “any solitary confinement setting” (Rezaq v. Nalley, 2012, p. 1015); and (3) did not increase the duration of their sentences and was not indeterminate because of the availability of periodic reviews (Shoats v. Horn, 2000, p. 144; Trujillo v. Williams, 2006, p. 1225).

The Eleventh Circuit held that an inmate does not have any liberty interest in avoiding 15-days of disciplinary segregation that does not result in loss of any good-time credit and where conditions of confinement (e.g., lack of writing surface, lock for storage bin, and a television) do not represent such “dramatic departure” from ordinary prison life (Smith v. Deemer, 2016, p. 868). Atypical and significant hardship must exist for a "significant period of time" and must be 
CONSTRUING THE LEGALITY OF SOLITARY CONFINEMENT

“severe relative to regular prison” (Smith v. Deemer, 2016, p. 868). Administrative confinement for 30-days (Sandin v. Conner, 1995) or 60-days (Rodgers v. Singletary, 1998) does not impose atypical and significant hardship, but segregation for 500-days (Magluta v. Samples, 2004) or one-year (Williams v. Fountain, 1996) constitutes atypical and significant hardship.

\section{Assessing Baselines of Comparison}

The Supreme Court declined to define the baseline from which to compare what is “atypical and significant hardship” (Sandin v. Conner, 1995; Wilkinson v. Austin, 2005). Appendix 1 describes the different baselines of comparison used by the different U.S. Circuit Courts of Appeals including: (1) general population conditions at the same institution (Beverati v. Smith, 1997; Hill v. Fleming, 2006; Keenan v. Hall, 1996; Penrod v. Zavaras,1996; Williams v. Lindamood, 2013, p. 561); (2) other types of administrative segregation, including protective custody, in the particular state’s penal system (Gaines v. Stenseng, 2002; Griffin v. Vaughn, 1997; Jones v. Baker, 1998; Wagner v. Hanks, 1997, pp. 1175-1176); (3) conditions experienced by “other inmates in the same segregation” unit (Gaines v. Stenseng, 2002, pp. 1225-1226; Hill v. Fleming, 2006, p. 666); (4) experiences of other "uniquely placed or difficult to place prisoners” (e.g., physically or mentally ill or dependent inmates, elderly inmates, or inmates with disabilities) (Estate of DiMarco v. Wyoming Department of Corrections, 2007, pp. 1341-1342); and, (5) "the most restrictive confinement conditions routinely imposed on inmates serving similar sentences” (Hatch v. District of Columbia, 1999, pp. 847, 856); or, at the "harshest facility in the state's most restrictive prison” (Aref v. Lynch, 2016, p. 254; Wagner v. Hanks, 1997, p. 1175).

The Second Circuit conducts “a fact-specific determination,” comparing the duration and 
conditions of plaintiff's segregation with those in similar administrative confinement and the general population (Aref v. Lynch, 2016, p. 254; Arce v. Walker, 1998, p. 336; Brooks v. DiFasi, 1997, pp. 48-49). The Third and Tenth Circuits generally use other forms of administrative segregation in the same prison as the baseline of comparison (Allah v. Bartkowski, 2014; Fantone v. Latini, 2015; Gaines v. Stenseng, 2002; Griffin v. Vaughn, 1997; Jones v. Baker, 1998). Both the Sixth and Eleventh Circuits require the plaintiff to present evidence on the “precise conditions of ordinary prison life prior to placement” (Williams v. Lindamood, 2013, p. 561) and that the segregation involved a “major disruption to his environment” compared to “placement in the general population” (Smith v. Regional Director of Florida, 2010, p. 13). The Tenth Circuit acknowledged that its “own opinions” have "inconsistently used comparisons either with inmates in the same segregation or those in the general prison population” (Ajaj v. U.S., 2008, p. 585; Jordan v. FBOP, 2006, p. 650).

In Allah v. Bartkowski (2014, p. 137), Allah was transferred to Management Control Unit Detention (“MCU”), a “close-custody” solitary confinement unit where he was: (1) isolated in a small cell in a block that contained mentally ill inmates; (2) restricted to 10-minute showers daily and a 90-minute yard period every second or third day; and, (3) not permitted access to toilets during the 90-minute yard period, causing him to sometimes relieve himself while in the yard. The Third Circuit concluded that the duration and conditions of Allah's confinement implicate a liberty interest because plaintiff was confined in the MCU for six-years and conditions in the MCU were significantly more restrictive than conditions in administrative segregation in the same prison (Allah v. Bartkowski, 2014; Jago v. Van Curen, 1981; Shoats v. Horn, 2000).

In a later case involving inmates who were kept on death row for several years after their 
death sentences were vacated, the Third Circuit used the general population conditions as a baseline for comparison (Williams v. Secretary Pennsylvania Department of Corrections, 2017). Here, two inmates remained several years on death row after their death sentences were vacated. One inmate spent approximately 20-years on death row, eight of which were spent after he was granted a resentencing hearing. Another inmate spent 22-years on death row, six of which were spent after he was granted a resentencing hearing. While on death row, plaintiffs were confined in a windowless seven by 12-feet cell for almost 24-hours daily, deprived of communication with the general population, and allowed four non-legal visits per month, during which they were locked in a "closet-sized room” behind a "reinforced sheet of glass" and not permitted physical contact with visitors (p. 554). The Third Circuit held that the plaintiffs demonstrated atypical and significant hardship. Their continued placements on death row were indefinite, lasting for years without any specific date for their transfer to general population. The court observed that other forms of segregation, such as punitive segregation are often "predetermined and fixed,” unless the inmate's behavior requires additional periods of segregation (p. 562). The court also noted that conditions on death row different "significantly" from "routine prison conditions" in the state’s correctional institutions (p. 563). Inmates in general population have access to: open air activities without strip searches, windows, natural light, daily showers, more frequent visits where contact is allowed, group religious services, jobs and vocational programs (e.g., clothing factory jobs, culinary training, and barbershop training), group sport activities, and unlimited phone calls as long as they could afford them.

The Fourth Circuit reiterated that there is no single standard for determining the baseline of comparison (Beverati v. Smith, 1997; Incumaa v. Stirling, 2015; Prieto v. Clarke, 2015; 
Ramirez v. Galaza, 2003). The atypicality baseline should be determined "in relation to the ordinary incidents of prison life" since confinement conditions will vary "depending on a particular inmate’s conviction” (Lovelace v. Lee, 2006, p. 202). A fact specific “case-by-case” approach should consider conditions routinely imposed on "inmates serving comparable sentences” (Prieto v. Clarke, 2015, p. 254; Rezaq v. Nalley, 2012, p. 1012). The Fourth Circuit used the general population as a baseline for atypicality in Beverati v. Smith (1997) because state prison regulations granted inmates in administrative segregation almost the same privileges of general population inmates, including at least "one-hour of recreation outside their cells sevendays per week" and "substantially the same access to prison services and educational programming” (pp. 503-504). In the subsequent case of Prieto v. Clarke (2015, p. 253), however, the Fourth Circuit cautioned that the "baseline for atypicality" is not always the general prison population but may vary depending on the "prisoner's conviction and sentence.” The Fourth Circuit affirmed that the general population is the baseline for atypicality for inmates sentenced to confinement in the general prison population but later transferred to security detention (Incumaa v. Stirling, 2015, p. 527).

In Incumaa v. Stirling (2015), an inmate who was a member of the Islamic extremist group Nation of Gods and Earths (the "Five Percenters”) participated in a 1995 riot with other Five Percenters in a prison operated by the South Carolina Department of Corrections (the "Department”). Following this riot, the Five Percenters were designated as a Security Threat Group. Plaintiff was then transferred from general population to the Maximum Security Unit, the most restrictive security detention in prison. He was later transferred to the Special Management Unit (“SMU”), a less restrictive detention. The Fourth Circuit held that plaintiff's 20-year period 
CONSTRUING THE LEGALITY OF SOLITARY CONFINEMENT

of segregation imposed atypical and significant hardship, using the general population as a baseline for comparison (Burnette v. Fahey, 2012; Incumaa v. Stirling, 2015). The Fourth Circuit found that plaintiff's confinement conditions were severely restrictive compared to general population conditions. He was subjected to daily cavity and strip searches, confined to a small cell, with only 10-hours of activity outside the cell per month, prohibited from socializing with other inmates, and denied educational, vocational, and therapy programs. Also, his confinement to the SMU is “extraordinary in its duration and indefiniteness” (Incumaa v. Stirling, 2015, p. 531).

In Wilkerson v. Goodwin (2014, p. 855), the Fifth Circuit considered the duration of solitary confinement, the severity of the restrictions, and its "effectively indefinite nature," concluding that plaintiff inmate’s segregation imposed an "atypical and significant hardship” under “any possible baseline.” The Fifth Circuit pointed out that the inmate’s 39-year segregation was "almost five times the duration deemed sufficient to give rise to a liberty interest in Shoats v. Horn (2000). The Fifth Circuit clarified that short periods in segregation that do not give rise to a liberty interest range from 12-months (Hernandez v. Velasquez, 2008), 15-months (Griffin v. Vaughn, 1997), and two-and-one-half years (Jones v. Baker, 1998).

The Fifth Circuit compared conditions of plaintiff's 39-years of administrative segregation to conditions of general population inmates, conditions in segregated confinement within the Louisiana system as a whole, and conditions of other inmates serving life sentences (Wilkerson v. Goodwin, 2014). The court noted that plaintif was: (1) confined alone to his cell for 23-hours per day with one-hour allotted for exercise and shower; (2) denied religious or educational opportunities, and (3) denied other privileges available to inmates in the general 
population. His segregation was also indefinite and static because the reviewing board routinely repeated the initial reason for placement in lockdown as the same reason for continued confinement. The Fifth Circuit concluded that the plaintiff's approximately 40-year segregation is "so atypical" that no other inmate in Louisiana has been confined for the same period (p. 856).

The Ninth Circuit declined to identify an appropriate baseline of comparison in Brown v. Oregon Dept. of Corrections (2014, p. 984) because “under any plausible baseline,” plaintiff’s 27-month administrative segregation in the Intensive Management Unit ("IMU”) without meaningful review imposed on him atypical and significant hardship. The Brown case involved a state inmate who was assigned to the IMU for 27-months after being found in possession of a weapon. IMU inmates are confined in single-man cells for more than 23-hours per day, spend only 40-minutes daily outside their cells, allowed two non-contact visits per month and a maximum of two visitors in a six-month period, and denied access to privileges granted to general population inmates (e.g., prison and law libraries, group religious services, educational and vocational opportunities, telephone use except in emergencies, televisions, and personal property). The Ninth Circuit observed that the plaintiff was isolated almost 23-hours each day and denied most privileges granted to general population inmates. His IMU confinement was fixed and irreducible, lasting for 27-months compared to the limited period of confinement and periodic reviews given to inmates in other segregated-housing units. The Ninth Circuit observed that the inmate did not receive any meaningful review during his 27-month segregation in IMU. The Ninth Circuit, however, affirmed the grant of summary judgment for the defendants based on qualified immunity because prior to this case, the court had not resolved the issue of "whether the absence of post-placement periodic, meaningful review” implicates a protected liberty 
interest (Brown v. Oregon Dept. of Corrections, 2014, p. 988; Harlow v. Fitzgerald, 1982, p. 818; Hope v. Pelzer, 2002, p. 741; Pearson v. Callahan, 2009, p. 244; Porter v. Bowen, 2007, pp. 1026-1027; Schwenk v. Hartford, 2000, pp. 1195-1196; U.S. v. King, 2012, p. 1189). It would grant such a liberty interest, moving forward in future cases.

The Tenth Circuit declined to make a "rigid either/or assessment” of any baseline, instead opting to "outline four potentially relevant, nondispositive factors," including whether: (1) the segregation relates to and furthers a "legitimate penological interest, such as safety or rehabilitation"; (2) the placement conditions are "extreme”; (3) the placement "increases the duration of confinement"; and, (4) the placement is "indeterminate” (Estate of DiMarco v. Wyoming Department of Corrections, 2007, p. 1342; Rezaq v. Nalley, 2012, p. 1012). The proper baseline approach for the Tenth Circuit is a "fact-driven assessment" that considers the "totality of conditions presented by a given inmate’s sentence and confinement” (Rezaq v. Nalley, 2012).

The Tenth Circuit considered both the general prison population and inmates in the same segregation unit as the baseline for comparison in Jordan v. FBOP (2006). In Jordan, a state inmate who was transferred to administrative detention pending investigation of a fellow inmate’s murder received written notice explaining the reasons for his segregation. The Tenth Circuit affirmed the lower court's grant of summary judgment for defendants because plaintiff did not show that his administrative detention imposed "atypical and significant hardship” compared to "either the general population or those in the same administrative detention" (p. 652). While in segregation, he also received the same privileges as inmates in general population (except for group recreation). He experienced restrictions and conditions comparable to those of the general inmate population, except for one less social call per month and seven-hours a week 
CONSTRUING THE LEGALITY OF SOLITARY CONFINEMENT

less recreation time.

The Eleventh Circuit arrived at a similar decision in Turner v. Warden (2016), where an inmate was placed in the special management unit ("SMU”) of the Georgia State Prison. The SMU houses high-risk inmates with a history of disciplinary problems; it consists of six wings identified according to inmate restrictions from highest restriction to lowest restriction. The Eleventh Circuit held that the plaintiff did not have any protected liberty interest in avoiding segregation in SMU because SMU conditions were similar to those in the general population, other types of administrative segregation, and protective custody (Delgiudice, Jr. v. Primus, 2017). Plaintiff received regular meals, five-hours of weekly outdoor recreation, and a shower period three-times weekly. Unless he was in the most restrictive wing, he was allowed to keep personal property, have a television in his cell, experience human contact, and receive visitors on weekends.

The D.C. Circuit adopted a “multi-factor approach” for determining the appropriate baseline of comparison in Hatch v. District of Columbia (1999, pp. 856-858). The court said that a liberty interest arises only when the deprivation imposes an atypical and significant hardship “in relation to the most restrictive confinement conditions that prison officials ... routinely impose on inmates serving similar sentences” (pp. 856). The court used administrative segregation, the "most routinely imposed” disciplinary measure of isolation, as a baseline of comparison (p. 856). It scrutinized both the nature and length of the deprivation to determine atypicality of hardship. The court in Hatch court remanded the case for the district court to determine whether conditions of the inmate’s 29-week segregation was comparable to normal conditions of administrative segregation and whether its duration was "atypical" compared to the 
"length of administrative segregation routinely imposed on similarly situated prisoners" (Aref v. Lynch, 2016, p. 254).

In Aref v. Lynch (2016, p. 257), the D.C. Circuit concluded that confinement in the FBPO Communication Management Units (“CMU”) involved “significantly less deprivation than administrative segregation.” This case involved several inmates who were convicted of terrorism-related activities and transferred to the two CMUs in Indiana and Illinois. The CMUs were established in response to a perceived “deficiency” in the monitoring of inmate communications that "allowed several inmates with terrorism-related convictions to communicate with extremist groups outside the prisons” (p. 246). The D.C. Circuit compared the conditions of inmates in administrative segregation with the conditions of inmates confined in the CMUs. The court noted that inmates in administrative segregation remain in their cells for 23-hours a day, cannot work or access educational opportunities, have limited possessions of materials, can exercise only one-hour daily for five-days a week, are allowed only one 15-minute phone call per month, and are permitted to have four-hours of non-contact visits per month. CMU inmates can access common spaces for 16-hours a day, have access to educational and professional opportunities, can possess property, have no exercise restrictions, can make two 15minute calls per week, and are allowed two four-hour non-contact visits per month. The court nonetheless acknowledged that CMU confinement is indefinite and atypical because “only a handful are placed under these restrictions” (p. 257). The court found a liberty interest in CMU designation because it "seems analogous to a classification," is exercised "selectively," and its duration "is indefinite and could be permanent” (p. 257). Although the deprivations are not extreme, they “necessarily increase in severity over time”-communication restrictions in 
administrative segregation last only during the period of segregation while restrictions in CMU may last indefinitely (p. 257). Having found a protected liberty interest, the court remanded the case for the district court to determine what type of due process is required.

\section{DISCUSSION AND CONCLUSION}

This article shows that the 12 U.S. Circuit Courts of Appeals have varying interpretations of the legal standards for determining the constitutionality of inmate segregation. They diverge on whether duration, confinement conditions, or a combination of both implicate liberty interests requiring due process protections, which segregation conditions impose atypical and significant hardship, and the baselines of comparison from which to determine atypicality of hardship. The lack of uniformity across the Circuits mean that inmates in some areas of the country are subject to longer terms of segregation and harsher conditions of confinement when compared to inmates in other areas. Moreover, the case law reported in this article shows that even when inmates prevail in their litigation, entitling them to due process protections, they may already have served months, years, and, in some cases, decades in solitary isolation cells (Campbell, 2016).

The U.S. Supreme Court's lack of guidance has helped to foster these divergent opinions in the lower courts, and in the absence of more definitive guidelines, lower courts will continue to differ in both their interpretations and outcomes of inmate segregation litigation. These conflicts among the Circuits invite the Supreme Court to further clarify what the Constitution requires of prison officials when segregating inmates. Analyzing these segregation cases also exposes a disconnect between the law and scholarly research—while the law permits segregation of inmates for months and years, there is an overwhelming scholarly consensus that long-term isolation irreparably harm inmates (Henderson, 2015), promotes post-traumatic stress disorder 
(Hagan et al., 2017), increases suicidal ideation (Hayes, 2017), and makes mentally ill inmates much worse (Haney \& Lynch, 1997).

The Supreme Court created the legal construct of atypical and significant hardship to determine the legality of solitary confinement in the cases of Sandin v Conner (1995) and Wilkinson v. Austin (2005). Various federal courts are required to apply and interpret this legal construct when deciding inmate litigation challenging their conditions of segregation. As an abstract concept, it is susceptible to different interpretations and a federal court has the option to possibly assess various mental and physical symptoms when determining atypicality and significance of hardship. However, courts do not interpret the construct to include the negative consequences on the mental and physical health of inmates. Instead, courts examine the duration and severity of the segregation conditions compared to different baselines. A more scientifically grounded interpretation would require courts to include an assessment of the harmful effects of solitary confinement, an approach that is not foreclosed by the legal standard of atypical and significant hardship.

Why does the law give short shrift to the harmful effects of long-term isolation/administrative segregation on inmates? Based on separation of powers, federalism, and remnants of the "hands-off” doctrine, the Supreme Court (Turner v. Safley, 1987, p. 89) and lower federal courts (Oliver v. Scott, 2002, p. 745) have given state prison officials much discretion in how they operate prison facilities. Judicial deference to prison administrators leads the legal analysis of the constitutionality of segregation to focus on the technocratic vicissitudes of the law, not on the harmful physical and mental outcomes wrought onto inmates. When assessing the constitutionality of segregation, courts need to focus more on the length of 
CONSTRUING THE LEGALITY OF SOLITARY CONFINEMENT

detention, the type of conditions of confinement to which inmates are exposed, and the outcomes such segregation has on inmates' mental and physical health. While inmates possess limited liberty interests when segregated, such due process protections offer few reprieves from the dreadful effects of solitary confinement and punitive administrative segregation exacted on inmates housed in the nations prisons.

\section{REFERENCES}

Allen-Bell, A. (2012). Perception, profiling, and prolonged solitary confinement viewed through the lens of the Angola 3 case: When prison officials become judges, judges become visually challenged, and justice becomes legally blind. Hastings Constitutional Law Quarterly, 39, 763-820.

Beck, A. (2015). Use of restrictive housing in U.S. prisons and jails, 2011-12. U.S. Department of Justice. Washington, DC: Bureau of Justice Statistics. NCJ 249209. Available at https://www.bjs.gov/content/pub/pdf/urhuspj1112.pdf

Binelli, M. (2015, March 26). Inside America’s toughest federal prison. New York Times Magazine. Available at https://www.nytimes.com/2015/03/29/magazine/inside-americastoughest-federal-prison.html

Campbell, M. (2016). Vulnerable and inadequately protected: Solitary confinement, individuals with mental illness, and the laws that fail to protect. Hofstra Law Review, 45, 263-298.

Freckelton, I. (2011). Cruel and unusual punishment of prisoners with mental illnesses: from oates to plata. Psychiatry, Psychology, \& Law, 18, 329-340.

Frost, N. and Monteiro, C. (2016). Administrative segregation in U.S. prisons. (DOJ, National Institute of Justice), 1-38, https://www.ncjrs.gov/pdffiles1/nij/249749.pdf 
Grassian, S. (2006). Psychiatric effects of solitary confinement. Washington University Journal of Law \& Policy, 22, 325-383.

Grassian, S. (1983). Psychopathological effects of solitary confinement. American Journal of Psychiatry, 140, 1450-1453 (1983).

Hagan, B. et al. (2017). History of solitary confinement is associated with post-traumatic stress disorder symptoms among individuals recently released from prison. Journal of Urban Health. First online. Available at https://doi.org/10.1007/s11524-017-0138-1

Haney, C. (2003). Mental health issues in long-term solitary and "supermax" confinement. Crime \& Delinquency, 49, 124-156.

Haney, C. (2018). Restricting the use of solitary confinement. Annual Review of Criminology, 1, 285-310.

Haney, C., \& Lynch, M. (1997). Regulating prisons of the future: A psychological analysis of supermax and solitary confinement. New York University Review of Law \& Social Change, 23, 477-570.

Hayes, L. (2017, November 5). Guiding principles and liability reduction with a viable suicide prevention program. Presentation to the National Commission on Correctional Health Care conference, held in Chicago, IL.

Henderson, G. (2015). Disciplinary segregation: How the punitive solitary confinement policy in federal prisons violates the due process clause of the Fifth Amendment in spite of Sandin v. Conner. Marquette Law Review, 99, 477-509. 
Johnson, R. (2016). Solitary confinement until death by state-sponsored homicide: An Eighth Amendment assessment of the modern execution process. Washington \& Lee Law Review, 73, 1213-1242.

Korn, R. (1988). The effects of confinement in the high security unit at Lexington. Social Justice, 15, 8-19.

Kupers, T.A. (2017). Solitary: The inside story of supermax isolation and how we can abolish it. Oakland, CA: University of California Press.

Lee, G., \& Prabhu, M. (2015). A reflection on the madness in prisons. Stanford Law and Policy Review, 26, 253-268.

Marcus, E. (2015). Toward a standard of meaningful review: Examining the actual protections afforded to prisoners in long-term solitary confinement. University of Pennsylvania Law Review, 163, 1159-1198.

McGinnis, K., Austin, J., Becker, K., Fields, L., Lane, M., Maloney, M.,...Felix, T. (2014). Federal bureau of prisons: Special housing unit review and assessment. Arlington, VA: CNA. Available at https://www.bop.gov/resources/news/pdfs/CNASHUReportFinal_123014_2.pdf

Nolasco, C., del Carmen, R. V., Steinmetz, K., Vaughn, M., \& Spaic, A. (2015). Building legal competency: Foundations for a more effective criminology and criminal justice discipline. Journal of Criminal Justice Education, 26(3), 233-252.

Nolasco, C., Vaughn, M., \& del Carmen, R. (2010). Toward a new methodology for legal research in criminal justice. Journal of Criminal Justice Education, 21, 1-23. 
CONSTRUING THE LEGALITY OF SOLITARY CONFINEMENT

National Commission on Correctional Health Care. (2016). Position statement: Solitary confinement (Isolation). Chicago: National Commission on Correctional Health Care. Available at https://www.ncchc.org/filebin/Positions/Solitary-Confinement-Isolation.pdf

Obama, B. (2016, January 25). Why we must rethink solitary confinement. Washington Post. Available at https://www.washingtonpost.com/opinions/barack-obama-why-we-mustrethink-solitary-confinement/2016/01/25/29a361f2-c384-11e5-89650607e0e265ce_story.html?tid=ss_mail\&utm_term=.036dbf6a6318

O'Keefe, M. L. (2008). Administrative segregation from within: A corrections perspective. The Prison Journal, 88(1), 123-143.

Reiter, K. (2016). 23/7: Pelican Bay prison and the rise of long-term solitary confinement. New Haven, CT: Yale University Press.

Rivlin, A., Fazel, S., Marzano, L., \& Hawton, K. (2013). The suicidal process in male prisoners making near-lethal suicide attempts. Psychology, Crime \& Law,19,305-327. DOI: 10.1080/1068316X.2011.631540

Shames, A., Wilcox, J., \& Subramanian, R. (2015, May). Solitary confinement: Common misconceptions and emerging safe alternatives. New York: VERA Institute of Justice. Available at https://storage.googleapis.com/vera-webassets/downloads/Publications/solitary-confinement-common-misconceptions-andemerging-safe-alternatives/legacy_downloads/solitary-confinement-misconceptions-safealternatives-report_1.pdf

Smith, P. (2006). The effects of solitary confinement on prison inmates: A brief history and review of the literature. Crime \& Justice, 34, 441-528. 
U.S. Department of Justice. (2016). Report and recommendations concerning the use of restrictive housing: Final report. Washington, DC: U.S. Department of Justice. Available at https://www.justice.gov/archives/dag/file/815551/download

U.S. House of Representatives Committee on Appropriations, Subcommittee on Financial Services and General Government, Budget. (2015, March 23). Budget hearing: The Supreme Court of the United States, FY 2016 Budget. Video of Justices Kennedy and Breyer testifying. Available at https://www.youtube.com/watch?v=spLCISTFF9k

\section{CASES CITED}

Abbott v. McCotter, 13 F.3d 1439 (10th Cir. 1994).

Ajaj v. United States, 293 Fed.Appx. 575 (10th Cir. 2008).

Allah v. Bartowski, 574 Fed.Appx. 135 (3rd Cir. 2014).

Arce v. Walker, 139 F.3d 329 (2nd Cir.1998).

Aref v. Lynch, 833 F.3d 242 (D.C. Cir. 2016).

Bailey v. Fisher, 647 Fed.Appx. 472 (5th Cir. 2016).

Bass v. Perrin, 170 F.3d 1312 (11th Cir. 1999).

Bell v. Wilkinson, 145 Fed.Appx. 169 (6th Cir. 2005).

Benjamin v. Fraser, 264 F.3d 175 (2nd Cir. 2001).

Beverati v. Smith, 120 F.3d 500 (4th Cir. 1997).

Bingham v. Thomas, 654 F.3d 1171 (11th Cir. 2011).

Brooks v. DiFasi, 112 F.3d 46 (2nd Cir. 1997).

Brown v. Oregon Dept. of Corrections, 751 F.3d 983 (9th Cir. 2014).

Burnette v. Fahey, 687 F.3d 171 (4th Cir.2012). 
Burns v. Pa. Dep't. of Corr., 642 F.3d 163 (3rd Cir.2001).

Bryan v. Duckworth, 88 F.3d 431 (7th Cir. 1996).

Carson v. Johnson, 112 F.3d 818 (5th Cir.1997).

Chappell v. Mandeville, 706 F.3d 1052 (9th Cir. 2013).

Colon v. Howard, 215 F.3d 227 (2nd Cir. 2000).

Cruz v. Forrest, 350 Fed.Appx. 900 (5th Cir. 2009).

Davis v. Ayala, 135 S.Ct. 2187 (2015).

Deberry v. Davis, 460 Fed.Appx. 796 (10th Cir. 2012).

Delgiudice, Jr. v. Primus, 679 Fed.Appx. 944 (11th Cir. 2017).

Diaz v. Canino, 502 Fed.Appx. 214 (3rd Cir. 2012).

Duffy v. Riveland, 98 F.3d 447 (9th Cir. 1996).

Earl v. Racine Cnty. Jail, 718 F.3d 689 (7th Cir. 2013).

Estate of DiMarco v. Wyoming Department of Corrections, 473 F.3d 1334 (10th Cir. 2007).

Evans v. Vinson, 427 Fed.Appx. 437 (6th Cir. 2011).

Fantone v. Latini, 780 F.3d 184 (3rd Cir. 2015).

Fogle v. Pierson, 435 F.3d 1252 (10th Cir. 2006).

Furrow v. Marberry, 412 Fed.Appx. 880 (7th Cir. 2011).

Gaines v. Stenseng, 292 F.3d 1222 (10th Cir. 2002).

Giano v. Selsky, 238 F.3d 223 (2nd Cir. 2001).

Goff v. Burton, 7 F.3d 734 (8th Cir.1993).

Gowadia v. Stearns, 596 Fed.Appx. 667 (10th Cir. 2014).

Greenholtz v. Inmates, 442 U.S. 1 (1979). 
Griffin v. Vaughn, 112 F.3d 703 (3rd Cir. 1997).

Hallman v. Cate, 483 Fed.Appx. 381 (9th Cir. 2012).

Harbin-Bey v. Rutter, 420 F.3d 571 (6th Cir. 2005).

Harden-Bey v. Rutter, 524 F.3d 789 (6th Cir. 2008).

Hardaway v. Meyerhoff, 734 F.3d 740 (7th Cir. 2013).

Harlow v. Fitzgerald, 457 U.S. 800 (1982).

Harris v. Caruso, 465 Fed.Appx. 481 (6th Cir. 2012).

Hatch v. District of Columbia, 184 F.3d 846 (D.C. Cir. 1999).

Heard v. Caruso, 351 Fed.Appx. 1 (6th Cir. 2009).

Hernandez v. Velasquez, 522 F.3d 556 (5th Cir. 2008).

Hewitt v. Helms, 459 U.S. 460 (1983).

Hill v. Fleming, 173 Fed.Appx. 664 (10th Cir. 2006).

Holly v. Woolfolk, 415 F.3d 678 (7th Cir. 2005).

Hope v. Pelzer, 536 U.S. 730 (2002).

Hoskins v. Lenear, 395 F.3d 372 (7th Cir. 2005).

Huff v. Thaler, 518 Fed.Appx. 311 (5th Cir. 2013).

Incumaa v. Stirling, 791 F.3d 517 (4th Cir. 2015).

In re Long Term Admin. Segregation, 174 F.3d 464 (4th Cir. 1999).

In re Medley, 134 U.S. 160 (1890).

Iqbal v. Hasty, 490 F.3d 143 (2nd Cir. 2007).

Jago v. Van Curen, 454 U.S. 14 (1981).

Jimenez v. McQueen, 460 Fed.Appx. 458 (5th Cir. 2012). 
Jones v. Baker, 155 F.3d 810 (6th Cir. 1998).

Jordan v. Federal Bureau of Prisons, 191 Fed.Appx. 639 (10th Cir. 2006).

Joseph v. Curtin, 410 Fed.Appx. 865 (6th Cir. 2010).

Kalwasinski v. Morse, 201 F.3d 103 (2nd Cir. 1999).

Keck v. Zenon, 240 Fed.Appx. 815 (10th Cir. 2007).

Keenan v. Hall, 83 F.3d 1083 (9th Cir. 1996), amended by, 135 F.3d 1318 (9th Cir. 1998).

Lagerstrom v. Kingston, 463 F.3d 621 (7th Cir. 2006).

Lekas v. Briley, 405 F.3d 602 (7th Cir. 2005).

Lovelace v. Lee, 472 F.3d 174 (4th Cir. 2006).

Luken v. Scott, 71 F.3d 192 (5th Cir. 1995).

Magluta v. Samples, 375 F.3d 1269 (11th Cir. 2004).

Marion v. Columbia Corr. Inst., 559 F.3d 693 (7th Cir. 2009).

Marshall v. Ormand, 572 Fed.Appx. 659 (10th Cir. 2014).

McAdams v. Wyoming Department of Corrections, 561 Fed.Appx. 718 (10th Cir. 2014).

McCord v. Maggio, 910 F.2d 1248 (5th Cir. 1990), after remand, 927 F.2d 844 (5th Cir.1991).

McKeithan v. Beard, 322 Fed.Appx. 194 (3rd Cir. 2009).

McQuillion v. Duncan, 306 F.3d 895 (9th Cir. 2002).

Meachum v. Fano, 427 U.S. 215 (1976).

Means v. Larson, 580 Fed.Appx. 481 (7th Cir. 2014).

Meriwether v. Faulkner, 821 F.2d 408 (7th Cir.1987).

Mitchell v. Dupnik, 75 F.3d 517 (9th Cir. 1996).

Moody v. Baker, 857 F.2d 256 (5th Cir. 1988). 
Mujahid v. Meyer, 59 F.3d 931 (9th Cir. 1995).

Murphy v. Mo. Dep't. of Corr., 372 F.3d 979 (8th Cir. 2004).

Myron v. Terhune, 476 F.3d 716 (9th Cir. 2007).

Obriecht v. Raemisch, 565 Fed.Appx. 535 (7th Cir. 2014).

Olim v. Wakinekona, 461 U.S. 238 (1983).

Oliver v. Scott, 276 F.3d 736 (5th Cir. 2002).

Orellana v. Kyle, 65 F.3d 29 (5th Cir. 1995).

Orr v. Larkins, 610 F.3d 1032 (8th Cir. 2010).

Palmer v. Richards, 364 F.3d 60 (2nd Cir. 2004).

Pearson v. Callahan, 555 U.S. 223 (2009).

Penrod v. Zavaras, 94 F.3d 1399 (10th Cir. 1996).

Perkins v. Kansas Dep’t. of Corr., 165 F.3d 803 (10th Cir. 1999).

Pichardo v. Kinker, 73 F.3d 612 (5th Cir. 1996).

Porter v. Bowen, 496 F.3d 1009 (9th Cir. 2007).

Price v. Johnston, 334 U.S. 266 (1948).

Prieto v. Clarke, 780 F.3d 245 (4th Cir. 2015).

Ramirez v. Galaza, 334 F.3d 850 (9th Cir. 2003).

Rezaq v. Nalley, 677 F.3d 1001 (10th Cir. 2012).

Richardson v. Runnels, 594 F.3d 666 (9th Cir. 2010).

Rimmer-Bey v. Brown, 62 F.3d 789 (6th Cir.1995).

Rodgers v. Singletary, 142 F.3d 1252 (11th Cir. 1998).

Rodriguez v. Pearson, 473 Fed.Appx. 728 (9th Cir. 2012). 
Rollins v. Cain, 2011 WL 13121389 (5th Cir. 2011).

Sandin v. Conner, 515 U.S. 472 (1995).

Saylor v. Nebraska, 812 F.3d 637 (8th Cir. 2016).

Schwenk v. Hartford, 204 F.3d 1187 (9th Cir. 2000).

Serrano v. Francis, 345 F.3d 1071 (9th Cir. 2003).

Shoats v. Horn, 213 F.3d 140 (3rd Cir. 2000).

Skinner v. Cunningham, 430 F.3d 483 (1st Cir. 2005).

Smith v. Birkey, 447 Fed.Appx. 744 (7th Cir. 2011).

Smith v. Deemer, 641 Fed.Appx. 865 (11th Cir. 2016).

Smith v. Regional Director of Florida, 368 Fed.Appx. 9 (11th Cir. 2010).

Stallings v. Werholtz, 492 Fed.Appx. 841 (10th Cir. 2012).

Stephens v. Cottey, 145 Fed.Appx. 179 (7th Cir. 2005).

Suarez v. Palomino, 590 Fed.Appx. 733 (10th Cir. 2014).

Tellier v. Fields, 280 F.3d 69 (2d Cir. 2000).

Templeman v. Gunter, 16 F.3d 367 (10th Cir.1994).

Toston v. Thurmer, 689 F.3d 828 (7th Cir. 2012).

Townsend v. Cooper, WL 12871896 (E.D. Wisc. 2012), aff'd in part and rev'd in part, 759 F.3d 678 (7th Cir. 2014).

Townsend v. Fuchs, 522 F.3d 765 (7th Cir. 2008).

Trujillo v. Williams, 465 F.3d 1210 (10th Cir. 2006).

Turner v. Safley, 482 U.S. 78 (1987).

Turner v. Warden, 650 Fed.Appx. 695 (11th Cir. 2016). 
United States v. King, 687 F.3d 1189 (9th Cir. 2012).

United States v. Rahman, 189 F.3d 88 (2nd Cir. 1999).

United States v. Rezaq, 134 F.3d 1121 (D.C. Cir. 1998).

Wagner v. Hanks, 128 F.3d 1173 (7th Cir. 1997).

Watkins v. Lnu, 547 Fed.Appx. 409 (5th Cir. 2013).

Whitford v. Boglino, 63 F.3d 527 (7th Cir. 1995).

Wilkinson v. Austin, 545 U.S. 209 (2005).

Wilkerson v. Stalder, WL 6665452 (M.D. La. 2013), aff'd, Wilkerson v. Goodwin, 774 F.3d 845 (5th Cir. 2014).

Williams v. Fountain, 77 F.3d 372 (11th Cir. 1996).

Williams v. Lindamood, 526 Fed.Appx. 559 (6th Cir. 2013).

Williams v. Secretary Pennsylvania Department of Corrections, 848 F.3d 549 (3rd Cir. 2017).

Wolff v. McDonnell, 418 U.S. 539 (1974).

\section{LAWS CITED}

U.S. Constitution Amendment XIV.

Prison Litigation Reform Act (“PLRA”), 18 U.S.C. § 3626(a)(1)(A) 